\title{
Study on Body Development of Chinese Li Nationality Students
}

\author{
Jijin Sun ${ }^{1, a}$ and Yan Sheng ${ }^{1, b^{*}}$ \\ ${ }^{1}$ Qiongtai teachers college, Haikou, China \\ asjj2002033@163.com, bsjj2016@163.com \\ * The corresponding author
}

Keywords: Data analysis; Computer monitoring in Fitness; Health management; Minority nationality;

\begin{abstract}
To study the body development of Chinese Li nationality students of 7-18 years old, with the work of literature, survey, measurement and computer statistics, at last by independent samples T-test to compare the body health factors of Chinese Li nationality students, there were three compare methods, first is a compare with the whole students of Li nationality, the second was concerned with the Li nationality school boys or Li nationality school girls, the third was concerned with the compare of gender. The result shows that, From 2005 to 2015, in ten years, the Li nationality students' body have been changed much. First, the eyesight is better than before, the height and sitting height are higher, but the weight isn't more change than before, only the girls, the weight is increase. the more, the individual health environment is not good as ten years ago. To compare with the Li nationality students, in the height or in the weight, there are not big different now, only the sitting height of girls is always lower than boys, the Li nationality boy's trunk seems more slender than before. The whole society should remain a persistent concern in Li nationality students' life habitation, arrangement of spare time, and house education, which have an important influence at the body development of children.
\end{abstract}

\section{Introduction}

Li nationality is a minority nationality in China, which main live in Hainan island, with the development of Chinese minority area, the Li nationality peoples' life environment change from the mountain to the town, the Li nationality students begin them a new education career in town, in ten years, how the body development changed, what shall we do to help them, by the investigation of 2005 and 2015, perhaps you may find a good idea.

\section{Research objects and methods}

Research Objects. The objects include 7-18 years old Li nationality students, which the general number is 12217, among them, the school boy is 6315, the school girl is 5902, and 4783 in 2005, 7434 in 2015.

Research Methods. The main methods include literature, survey, measurement and statistics. And the measurement indexes are ascarid egg, eyesight, height, weight, and sitting height etc.

In the comparison of data, the main comparison object is average level; the statistics is independent samples T-test. which the original data comes from 2005 Chinese government's opened reports of physical fitness and health research of Chinese school students or recently[1][2][3].

\section{Results}

Body Changes of Li Nationality Students from 2005 to 2015. From2005 to 2015, 10 years after, the Li nationality students' body have been changed much. First, the eyesight is good than before, the height and sitting height are higher, but the weight is not apparent different than the last. Especially, the individual health habit is not good than ten years ago, for example, in 2005, the detection rate of ascarid egg is $12.65 \%$, but in 2015 , the rate is $14.92 \%$, the rate rise for over two percent. 
Table 1 Comparison on Body Changes of Li Nationality Students (2005-2015)

\begin{tabular}{|c|c|c|c|c|c|c|c|c|c|c|}
\hline \multirow{3}{*}{ Index } & \multirow{3}{*}{$\begin{array}{c}\text { Equal } \\
\text { variances } \\
\text { assumed or } \\
\text { not assumed } \\
(\text { Y or } \mathrm{N})\end{array}$} & \multicolumn{4}{|c|}{$\begin{array}{c}\text { Levene's Test for } \\
\text { Equality of } \\
\text { Variances } \\
\end{array}$} & \multicolumn{5}{|c|}{ t-test for Equality of Means } \\
\hline & & \multirow[t]{2}{*}{$\mathrm{F}$} & \multirow[t]{2}{*}{ Sig. } & \multirow[t]{2}{*}{$\mathrm{t}$} & \multirow[t]{2}{*}{ df } & \multirow[t]{2}{*}{$\begin{array}{l}\text { Sig.(2- } \\
\text { tailed) }\end{array}$} & \multirow[t]{2}{*}{$\begin{array}{c}\text { Mean } \\
\text { Differe } \\
\text { nce }\end{array}$} & \multirow{2}{*}{$\begin{array}{l}\text { Std.Err } \\
\text { or } \\
\text { Differe } \\
\text { nce }\end{array}$} & \multicolumn{2}{|c|}{$\begin{array}{l}95 \% \text { Confidence } \\
\text { Interval of the } \\
\text { Difference }\end{array}$} \\
\hline & & & & & & & & & Lower & Upper \\
\hline \multicolumn{11}{|l|}{ Ascarid } \\
\hline egg & Y & 15.522 & .000 & -3.253 & 4572 & .001 & -75.899 & 23.329 & -121.636 & -30.162 \\
\hline $\begin{array}{c}\text { left } \\
\text { eyesight }\end{array}$ & Y & 54.327 & .000 & -6.263 & 1709 & .000 & -4.326 & .691 & -5.681 & -2.971 \\
\hline Height & Y & 43.205 & .000 & -3.993 & 4690 & .000 & -9.5163 & 2.3831 & -14.1884 & -4.8443 \\
\hline Weight & $\mathrm{N}$ & .939 & .333 & -1.368 & 4700 & .171 & -.6571 & .4802 & -1.5986 & .2843 \\
\hline $\begin{array}{l}\text { Sitting } \\
\text { height }\end{array}$ & $\mathrm{Y}$ & 5.605 & .018 & -6.773 & 4700 & .000 & -1.7340 & .2560 & -2.2359 & -1.2321 \\
\hline
\end{tabular}

Body Changes of Li Nationality School Boys in 10 Years. Table 2 shows, compare from 2005 to 2015, the body of Li nationality boy has been changed greatly. Such as ascarid egg, height, weight and sitting height etc, they all can see obvious changes. From the table, we can see that the live environment of Li nationality boy maybe worse, in 2005 , the detection rate is $13.57 \%$, but in 2015 , the rate is $14.92 \%$. The height is higher than ten years ago, the number of difference is over 8.5 , the weight is as weight as the last ten years. And the sitting height is rise, it can see than the Li nationality boy's trunk is more slender than his father's period.

Table 2 Comparison on Body Changes of Li Nationality School Boys(2005-2015)

\begin{tabular}{|c|c|c|c|c|c|c|c|c|c|c|}
\hline \multirow{3}{*}{ Index } & \multirow{3}{*}{$\begin{array}{c}\text { Equal } \\
\text { variances } \\
\text { assumed or } \\
\text { not assumed } \\
(\mathrm{Y} \text { or } \mathrm{N})\end{array}$} & \multicolumn{2}{|c|}{$\begin{array}{c}\text { Levene's Test for } \\
\text { Equality of } \\
\text { Variances }\end{array}$} & \multicolumn{7}{|c|}{ t-test for Equality of Means } \\
\hline & & \multirow[t]{2}{*}{$\mathrm{F}$} & \multirow[t]{2}{*}{ Sig. } & \multirow[t]{2}{*}{$\mathrm{t}$} & \multirow[t]{2}{*}{$\mathrm{df}$} & \multirow[t]{2}{*}{$\begin{array}{l}\text { Sig.(2- } \\
\text { tailed) }\end{array}$} & \multirow[t]{2}{*}{$\begin{array}{c}\text { Mean } \\
\text { Differe } \\
\text { nce }\end{array}$} & \multirow{2}{*}{$\begin{array}{c}\text { Std.Erro } \\
\text { r } \\
\text { Differen } \\
\text { ce } \\
\end{array}$} & \multicolumn{2}{|c|}{$\begin{array}{c}95 \% \text { Confidence } \\
\text { Interval of the } \\
\text { Difference }\end{array}$} \\
\hline & & & & & & & & & Lower & Upper \\
\hline $\begin{array}{c}\text { Ascarid } \\
\text { egg }\end{array}$ & Y & 22.430 & .000 & -3.582 & 2372 & .000 & 129.020 & 36.018 & $\begin{array}{c}- \\
199.651\end{array}$ & -58.389 \\
\hline $\begin{array}{c}\text { left } \\
\text { eyesight }\end{array}$ & Y & 27.908 & .000 & -.965 & 911 & .335 & -.841 & .872 & -2.553 & .870 \\
\hline Height & Y & 57.825 & .000 & -2.544 & 2091.868 & .011 & -8.5153 & 3.3468 & -15.079 & -1.9519 \\
\hline Weight & $\mathrm{N}$ & .235 & .628 & .053 & 2424 & .958 & .0374 & .7091 & -1.3532 & 1.4279 \\
\hline $\begin{array}{l}\text { Sitting } \\
\text { height }\end{array}$ & $\mathrm{N}$ & 1.506 & .220 & -3.120 & 1918.388 & .002 & -1.2191 & .3907 & -1.9854 & -.4528 \\
\hline
\end{tabular}

Body Changes of Li Nationality School Girls in 10 Years. The same tendency can see from the Li nationality school girl. From the table 3, the ascarid egg detection rate is higher than ten years ago. In 2005 , the rate is $11.54 \%$, but now, the number is $14.92 \%$. The same phenomenon can tell us, the health environment of Li nationality is worrying. The girl's height is higher than the last, and the difference number is 10.908. And the weight, the sitting height is increase apparently now, the weight's number of increase is $1.8359 \mathrm{~kg}$, the sitting height's number of increase is $2.5661 \mathrm{~cm}$. 
Table 3 Comparison on Body Changes of Li Nationality School Girls(2005-2015)

\begin{tabular}{|c|c|c|c|c|c|c|c|c|c|c|}
\hline \multirow{3}{*}{ Index } & \multirow{3}{*}{$\begin{array}{c}\text { Equal } \\
\text { variances } \\
\text { assumed or } \\
\text { not assumed } \\
(\mathrm{Y} \text { or } \mathrm{N})\end{array}$} & \multicolumn{2}{|c|}{$\begin{array}{c}\text { Levene's Test for } \\
\text { Equality of } \\
\text { Variances }\end{array}$} & \multicolumn{7}{|c|}{ t-test for Equality of Means } \\
\hline & & \multirow[t]{2}{*}{$\mathrm{F}$} & \multirow[t]{2}{*}{ Sig. } & \multirow[t]{2}{*}{$\mathrm{t}$} & \multirow[t]{2}{*}{ df } & \multirow[t]{2}{*}{$\begin{array}{l}\text { Sig.(2- } \\
\text { tailed) }\end{array}$} & \multirow[t]{2}{*}{$\begin{array}{c}\text { Mean } \\
\text { Differe } \\
\text { nce }\end{array}$} & \multirow{2}{*}{$\begin{array}{c}\text { Std.Erro } \\
\text { r } \\
\text { Differen } \\
\text { ce } \\
\end{array}$} & \multicolumn{2}{|c|}{$\begin{array}{c}95 \% \text { Confidence } \\
\text { Interval of the } \\
\text { Difference }\end{array}$} \\
\hline & & & & & & & & & Lower & Upper \\
\hline $\begin{array}{c}\text { Ascarid } \\
\text { egg }\end{array}$ & Y & 19.681 & .000 & -3.510 & 2198 & .000 & -83.402 & 23.760 & -129.998 & -36.807 \\
\hline $\begin{array}{c}\text { left } \\
\text { eyesight }\end{array}$ & Y & 47.456 & .000 & -8.561 & 796 & .000 & -9.166 & 1.071 & -11.268 & -7.065 \\
\hline Height & Y & 4.747 & .029 & -3.374 & 1542.468 & .001 & -10.908 & 3.2325 & -17.248 & -4.5669 \\
\hline Weight & Y & 11.588 & .001 & -2.959 & 1561.032 & .003 & -1.8359 & .6204 & -3.0528 & -.6189 \\
\hline Sitting & Y & .095 & .758 & -8.039 & 2272 & .000 & -2.5661 & .3192 & -3.1921 & -1.9402 \\
\hline height & $\mathrm{N}$ & & & -8.033 & 1478.077 & .000 & -2.5661 & .3194 & -3.1927 & -1.9395 \\
\hline
\end{tabular}

Body Changes of Li Nationality Students between Gender. To compare from gender, with the table 4, we can see, in height, there have not big different between gender, and the sitting height of girls is always lower now. And in 2005, the boy's weight is weighty, but now, the state does not exist.

Table 4 Comparison on Body Changes of Li Nationality Students Between Gender

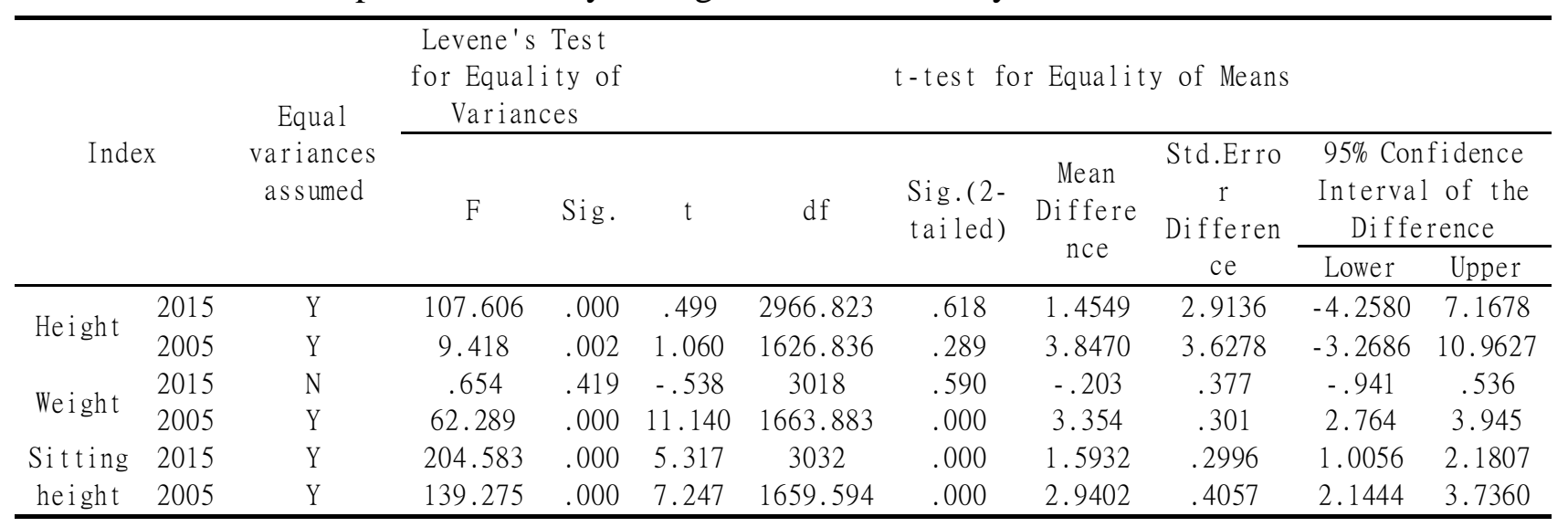

\section{Conclusion}

From2005 to 2015, 10 years after, the Li nationality students' body have been changed much. First, the eyesight is better than before, the height and sitting height are higher, but the weight isn't more change than before, only the girls, the weight is increase. the more, the individual health environment is not good than ten years ago. To compare with the Li nationality students, in the height and in the weight, there are not big different now, only the sitting height of girls is always lower than boys, the Li nationality boy's trunk seems more slender than before.

The whole society should remain a persistent concern in Li nationality students' life habitation, arrangement of spare time, and house education, which have an important influence at the body development of children.

\section{References}

[1] Research team: 2005 Reports on the Physical Fitness and Health Research of Chinese School Students (Higher Education Press, Beijing 2007).

[2] Research team: 2000 Reports on the Physical Fitness and Health Research of Chinese School Students (Higher Education Press, Beijing 2002). 
[3] Hao Wenting, Ni sigui and Cai sijie: The Research on Physical Health of Students in Hainan Province (Guangming Daily Press 2010).

[4] Hu Peijing, Ji Chengye: Comparative Study on Physical Constitution of Rural Students between Li and Han Nationality, J. Journal of China School Health. Commun. 26(2005)13-15.

[5] Xie Dong-li, Research Summary on Li nationality in China, J. Journal of Hubei University for Nationalities (Philosophy and Social Sciences), Commun. 30(2012)52-56.

[6] Zhang Liao, Yang Hui-qing, J. Analysis of the Somatotype of Li Teenagers in Hainan with Heath-Carter Method Contemporary Sports Technology, Commun. 4(2014)190-192.

[7] Jin Shan, Li minority traditional culture in social transition, J. Humanities and Social Sciences Journal of Hainan University, Commun. 27(2009)361-365.

[8] Jin Shan, A Tentative Survey on the Social Mobility of Hainan's Li Minority, J. Humanities and Social Sciences Journal of Hainan University, Commun. 30(2012)1-5.

[9] Zong Xue-fei, Totem and Traditional Sports of Li Nationality, J. Journal of the Central University for Nationalities, Commun. 32(2005)98-100.

[10]Sui Guo-zheng, Traced Analysis on Female Students'Constitution Health Criterion of LI Ethnic Group, J. Journal of Qiongzhou University, Commun. 17(2010)54-57. 